\title{
COMPETENCE OF HUMAN RESOURCES AND THE GOVERNMENT INTERNAL CONTROL SYSTEM (SPIP) AND THE EFFECTS ON THE FINANCIAL STATEMENT QUALITY OF PUBLIC SERCVICE AGENCY (BLU) MODERATED BY GOVERNMENT ACCOUNTING STANDARD (SAP)
}

\author{
Inggrid Panjaitan \\ University 17 Agustus 1945 Jakarta
}

\begin{abstract}
The aim of this research is to examine the effects of Human Resources Competence and the Government Internal Control System (SPIP) on the Quality of Financial Statements of the Public Service Agency with the Government Accounting Standard (SAP) as moderating variable. The research was conducted at the Public Service Agency of Government Hospital in Jakarta under the Ministry of Health. The sampling technique in this study used purposive sampling method (sampling intentionally in accordance with the requirements of samples required). Questionnaires were distributed as many as 85 questionnaires to some employees in the finance department and others that related to the making of financial statement at the Public Service Agency of Government Hospital under the Ministry of Health. The results showed that HR Competency significantly affected the quality of Public Service Agency Financial Statement. SPIP significantly affected the quality of Public Service Agency Financial Statement. Moderation of Government Accounting Standard (SAP) significantly affected and weakened the effect of HR Competency on the Quality of Public Service Agency Financial Statement. Moderation of Government Accounting Standards did not affect significant and strengthened the effect of SPIP on the Quality of Public Service Agency Financial Statement.
\end{abstract}

Keywords: Competence of Human Resources; Government Internal Control System; Quality of Financial Statement; Public Service Agency; Government Accounting Standards

\section{INTRODUCTION}

One of the important requirements in realizing financial management accountability is the presence of good financial statements. Demand to government institution today is the increase of transparency and accountability to the presentation of the information contained in the financial statements of public sector. The existence of Law Number 17 Year 2003 on State Finance is one of the real forms to actualize transparency and accountability in the management of state finances, which form and content of the implementation accountability report of the Indonesian Budget (APBN) or Regional Government Budget (APBD) prepared and presented in accordance with the Governmental Accounting Standards set by Government Regulation No. 24 Year 2005 which is further amended by Government Regulation No. 71 Year 2010 concerning the Government Accounting Standards. At the opening ceremony of Government Accounting and Financial Reporting National Working Meeting in 2014, the Finance Minister said that the Government has consistently made efforts to improve the quality of the states financial accountability.

*Inggrid Panjaitan 
Competence Of Human Resources and The Government Internal Control System (SPIP) and The Effects on The Financial Statement Quality Of Public Service Agency (BLU) Moderated by Government Accounting Standard (SAP)

lnggrid Panjaitan

Quality repair and improvement of the states financial accountability among other showed by the opinion of Supreme Audit Agency (BPK) on the Financial Statements of State Ministry / Institution that is getting better.

Table of Opinion Development on the Financial Statements of State Ministry / Institution Year 20092015

\begin{tabular}{|c|c|c|c|c|c|c|c|}
\hline $\begin{array}{l}\text { Supreme Audit Agency } \\
\text { Opinions }\end{array}$ & 2009 & 2010 & 2011 & 2012 & 2013 & 2014 & 2015 \\
\hline $\begin{array}{l}\text { Fair without Exceptions } \\
\text { (unqualified) }\end{array}$ & 45 & 53 & 61 & 62 & 65 & 62 & 85 \\
\hline $\begin{array}{l}\text { Fair with } \\
\text { (Qualified) }\end{array}$ & 26 & 28 & 17 & 22 & 19 & 18 & 2 \\
\hline $\begin{array}{ll}\text { Not Give } & \text { Opinion } \\
\text { (Disclaimer) } & \end{array}$ & 8 & 2 & 2 & 3 & 3 & 7 & 0 \\
\hline Total of Ministry / Institution & 79 & 78 & 80 & 87 & 87 & 87 & 87 \\
\hline
\end{tabular}

Source: www.kemenkeu.go.id

The realization of good financial statement cannot be separated from the competence of human resources that composes it. Human resources competency needed in order to determine the level of performance expected for the category of good or average. Standard of Human Resources Competency contains minimum requirements that must be owned by a person to do a particular job in order to have the ability to carry out the work with good results. According to Muins (2000: 40), Standard of competence is a measure to understand and communicate with different cultures and closely associated with professionalism". Competence of human resources is one of the most important factors in the preparation of financial statements for the creation of financial statements that have the quality of good information value. The preparation process of financial statements is the most important process of an organization to determine the performance in one period, then if it is not supported by the competence of the human resources in the finance department, so the implementation of government accounting standards and internal control systems is not effective so it cannot generate reliable financial statement. This research is a development of research conducted by (Sudiarianti, Ulupui, \& Budiasih, 2015) dan (Wati, Herawati, AK, \& SINARWATI, 2014). The research also makes the Government Accounting Standards as moderating variable. Grand theory used in this research is the Indonesian Government Regulation No. 71 Year 2010 which states that "the Government Accounting Standards is the principles of the accounting applied in preparing and presenting the government financial statements."

Annex II of Government Regulation No. 71 Year 2010 systematically and structured hints financial statements which produced by the government must contain accountability element that is responsible to the management of resources and policy implementation which is entrusted to reporting entities in achieving the goals that have been set on a periodically, management is to help users to evaluate the activities implementation of a reporting entity in the reporting period, so as to ease the function of planning, 
management and control over all assets, liabilities, and equity of government funds for the benefit of society, transparency is giving financial information that is open and honest to the public based on the consideration that public has a right to find out openly and comprehensively on government accountability in the management of the resources entrusted to them and their obedience to the laws and the balance between generations (intergenerational equity) that is to assist users in knowing the adequacy of government revenues in the reporting period to fund all expenses allocated and whether the future generation assumed will bear the burden of the expense.

The definition of Public Service Agency as published in Government Regulation No. 23 Year 2005 on the Financial Administration of the Public Service Agency (BLU) is as follows:

"Public Service Agency (Badan Layanan Umum) is an agency within the government that is formed to provide services to the public in the form of provision of goods and / or services sold without priority for profit and in conducting its activities based on the principles of efficiency and productivity."

In the frame of accountability for financial management and servicing activities, as stated in Minister of Finance Regulation (PMK) No. 76 / PMK.05 / 2008 on Guidelines of Accounting and Public Service Agency Financial Reporting of Budget Realization Report / Report of Operational, Balance, Cash Flow Statement, and Notes to Financial Statements and Performance Reports that is basic financial statements accompanied by the Performance Report which describes briefly and full of performance outcomes which contained a summary of the output from each activity and the results achieved from each program compiled in the Business and Budget Plan.

Institutionally, Public Service Agency (BLU) is a government agency that is inseparable from the state ministries / parent institutions. The development of BLU since it is established for the first time with the determination of Government Regulation 23 in 2005 quite rapidly, both in terms of the number of BLU and its economic social contribution. Until 2014, it had reached 141 government institutions which becoming BLU. BLU revenues reached more than Rp. 24-T in 2013, the higher the percentage on the non-tax revenues compared to previous years. This condition is expected able to improve BLU role as an agent of public service that accentuate efficiency and productivity so that the quality of public services itself increasingly felt by the public.

In line with its development, BLU existence cannot be separated from environmental conditions / BLU respective industry itself. Demands of professionalism and competition in its environment affect BLU to always improve become better. As in the hospital environment, the ultimate vision of hospitals in Indonesia is becoming a world class hospital, including the hospital of BLU. World-class context has various aspects. One of the aspects is the recognition from international community on the quality of Tridharma activities, infrastructure, management, financing and others. Demands which may be the same for others BLU fields such as universities, the fund manager or area manager. An important point from that matter is the quality of the BLU financial statements with the environment / industry. It is interesting to be deepened how accounting and reporting of BLU to answer the vision of BLU in the future which is professional and worldclass. 
Competence Of Human Resources and The Government Internal Control System (SPIP) and The Effects on The Financial Statement Quality Of Public Service Agency (BLU) Moderated by Government Accounting Standard (SAP)

lnggrid Panjaitan

HR Competency is an important and influential factor on the implementation and completion of jobs within an organization. With the presence of human resources competence, the time of making financial statement will be saved. It is due to the human resources have had knowledge and understanding concerning the things that must be done, so that the financial statements prepared can be completed and presented on time. The faster the financial statements are presented, the better in terms of decision-making (Mardiasmo, 2002: 146). Wati et al. (2014) found that the competence of human resources has a significant effect on the quality of financial statement. With the presence of human resources competence, then the role in planning, implementing, and controlling the organization will proceed well. If the competence of human resources properly implemented, then the quality of financial statements will be increased, so that good financial statement is able to meet the qualitative characteristics of financial statements. Thus, the competence of human resources is shown in order that the implementation of tasks and functions of the organization in order to generate qualified financial statement can be applied.

Based on the explanation above, it can be concluded that the competence of human resources will affect the quality of financial statement. So it can be made a hypothesis to be proved, namely:

H1: Competence of Human Resources (HR) significantly affects the quality of BLU financial statements.

Internal Control System (ICS) is a way to direct, monitor, and measure the resources of an organization, as well as play an important role in the prevention and detection of fraud. Judging from these objectives, the internal control system can be divided into two, namely:

\section{Accounting Internal Control}

It is made to prevent inefficiency. The goal is to maintain the wealth of the organization and check the accuracy of accounting data, for example, the separation of functions and responsibilities among organizational units.

\section{Administrative Control}

It is made to encourage efficiency and compliance to the management policies. For example is report audit to look for irregularities that exist, afterwards it is resolved.

It still found irregularities and leaks in the financial statements of government institute by the Supreme Audit Agency (BPK), pointed out that the government's financial statements have not met the characteristics / value information required. The results of the audit conducted by BPK, BPK provides opinions "unnatural and / or disclaimer" which are caused by the weakness of the Internal control system owned by related government institute. Sudiarianti et al. (2015) proves empirically that the application of SPIP and SAP has positive effect on the quality of government financial statement. The higher the application of Government Internal Control System (SPIP) and Government Accounting Standarrd (SAP) implemented, then, the quality of the resulted financial statements tends to be better. Based on the description above, this study is intended to examine the relationship between SPIP and the quality of financial statement. It can be drawn hypothesis as follows:

H2: Government Internal Control System (SPIP) affects positive on the Quality of BLU Financial

\section{Statement.}


Government accounting standards are accounting principles which applied in preparing and presenting the financial statements of the government. For that, it is required human resource that is able to meet accounting principles appropriate with government accounting standards. The goal is that the financial statements produced can improve the quality of government financial statement. The result of research conducted by (Udiyanti, Atmadja, \& Darmawan, 2014) concluded that the application of the Government Accounting Standards and Competence of HR on the financial statements which have been accountable is able to improve the quality of financial statements, to provide information for decisionmaking and have presented information on the revenues adequacy of the period runs for covering all the expenses. With the above description, it can be concluded for the third hypothesis, namely:

H3: Moderation of Government Accounting Standards is able to strengthen the effect of HR competence on the quality of BLU financial statement.

Government Accounting Standards is the cornerstone for the government in preparing and presenting financial statements in order to improve the quality of government financial statement. Government Accounting Standards (SAP) established by the Government Regulation No. 71 Year 2010 as a replacement of Government Regulation No. 24 of 2005. Government Accounting Standards (SAP) is stated in the form of Government Accounting Standards Statement (PSAP), equipped with an Introduction of Government Accounting Standards and compiled refer to the Government Accounting Conceptual Framework.

Internal Control System has function as a guideline in the implementation and effectiveness benchmark of the implementation of the Internal Control System, then on August 28, 2008 the Government issued Government Regulation (PP) No. 60/2008 about Government Internal Control System (SPIP) to answer the challenges of government bureaucracy in Indonesia in managing state finances. Sudiarianti et al. (2015), concludes that the application of SPIP and SAP has positive effect on the quality of government financial statement. The higher the application of SPIP and SAP implemented, then, the quality of the resulted financial statements tends to be better. Based on the description above, it can be concluded the fourth hypothesis as follows:

H4: Moderation of Government Accounting Standards is able to strengthen the effect of SPIP on the quality of BLU financial statement.

\section{METHODS}

This study was conducted at the Hospital Public Services Agency under the Ministry of Health, that was RSPI Prof. dr. Sulianti Saroso and RSUP Persahabatan. The reason for choosing the locations was due to the Public Service Agency is required to conduct effective and efficient financial management of BLU in order to support the increasing of services to the community. The population used in this study were all employees in the finance department and other parts that contributed to the preparation of the financial statements of the Public Service Agency under the Ministry of Health and the quality of financial statement to be generated. 
Competence Of Human Resources and The Government Internal Control System (SPIP) and The Effects on The Financial Statement Quality Of Public Service Agency (BLU) Moderated by Government Accounting Standard (SAP)

lnggrid Panjaitan

Samples in this study were 85 respondents. The samples were determined by using purposive sampling method, which meant the sample selection based on certain criteria. The criteria that were sampled, among others:

1. Government institutions that implement the Government Accounting Standards.

2. Government institutions which have had a complete financial data relating to the study variables.

3. The government instituttions that have conducted audit process on its financial statements every year either by an external audit of the government that is the Supreme Audit Agency (BPK) or the Office of Public Accountant and Internal audit by the Internal Audit Unit (IAU)

Type of research used in this research was quantitative descriptive method. Total of the population included in this study were 85 respondents. The respondents were willing to fill completely questionnaire given. The scale used to measure the opinion of respondents was a likert scale, that measuring the response of the subjects into five (5) points. Testing conducted in this study was the validity and reliability tests. While for hypothesis testing was a partial test ( $\mathrm{t}$ test), simultaneous test ( $\mathrm{F}$ test). The data was analyzed by using the method of Partial Least Square. PLS is an alternative method with Structural Equation Modelling (SEM) which based variance. The following table displays Outer Model and Inner Model studied in this study.

Here are described the definition and measurement of research variables:

Independent Variables (X Variable) in this study were:

\section{Competence of Human Resources}

Competence of Human Resources (HR) is a competency which relates to knowledge, skills, abilities, and personality characteristics that influence directly the performance.

2. Government Internal Control System (SPIP)

Sukmaningrum \& Harto (2012) states that internal control systems covering a wide range of management tools that aim to achieve various wide purposes. The purpose is to ensure compliance to the laws and regulations, ensure the reliability of financial statements and financial data, to facilitate the efficiency and effectiveness of government operations.

Dependent Variable (Y) which was influenced by independent variables in this study is the Financial Statements Quality of Public Service Agency. Quality of financial statement is very important as the quality of financial statements reflected the performance of the institution. The financial statement was prepared as good as possible that presented reasonable financial position. Fair presentation required truth presentation against the effects of transactions, other events and conditions in accordance with the criteria of government accounting standards and regulations prevailing in Indonesia.

Moderating variables $(Z)$ was a variable that had strong dependence effect (contingent effect) with the relationship between dependent variable and independent variables (Sekaran, 2006). Moderating variable in this research was the Government Accounting Standards which served as guidance in financial reporting to improve the quality of financial statement. 


\section{RESULTS AND DISCUSSION}

Table 1. Indicator of Human Resources Competencies Variable (Variable X1)

\begin{tabular}{|l|l|l|l|l|l|}
\hline & $\begin{array}{l}\text { Original } \\
\text { Sample } \\
(\mathrm{O})\end{array}$ & $\begin{array}{l}\text { Sample } \\
\text { Mean } \\
(\mathrm{M})\end{array}$ & $\begin{array}{l}\text { Standard } \\
\text { Deviation } \\
(\mathrm{STDEV})\end{array}$ & $\begin{array}{l}\mathrm{T} \text { Statistics } \\
(\mid \mathrm{O} / \text { STDEV })\end{array}$ & $\begin{array}{l}\mathrm{P} \\
\text { Values }\end{array}$ \\
\hline X1.P1 <- Variable X1 & 0,838 & 0,821 & 0,070 & 12,036 & 0,000 \\
\hline X1.P2 <- Variable X1 & 0,819 & 0,800 & 0,081 & 10,165 & 0,000 \\
\hline X1.P3 <- Variable X1 & 0,826 & 0,811 & 0,080 & 10,348 & 0,000 \\
\hline X1.P4 <- Variable X1 & 0,745 & 0,729 & 0,098 & 7,596 & 0,000 \\
\hline X1.P5 <- Variable X1 & 0,844 & 0,850 & 0,035 & 23,776 & 0,000 \\
\hline X1.P6 <- Variable X1 & 0,824 & 0,833 & 0,036 & 23,030 & 0,000 \\
\hline X1.P7 <- Variable X1 & 0,739 & 0,727 & 0,080 & 9,216 & 0,000 \\
\hline
\end{tabular}

In table 1 above is known that the correlation or relationship values between indicators and variables were strong. It showed the values of original sample of each indicator was greater than 0.5. Hence, the relationship between indicators that made up the variable of HR Competency had a validity value on each indicator.

Table 2. Indicator of Government Internal Control System (SPIP) Variable (Variable X2)

\begin{tabular}{|l|l|l|l|l|l|}
\hline & $\begin{array}{l}\text { Original } \\
\text { Sample } \\
(\mathrm{O})\end{array}$ & $\begin{array}{l}\text { Sample } \\
\text { Mean } \\
(\mathrm{M})\end{array}$ & $\begin{array}{l}\text { Standard } \\
\text { Deviation } \\
(\text { STDEV })\end{array}$ & $\begin{array}{l}\mathrm{T} \text { Statistics } \\
(\mid \mathrm{O} / \text { STDEV })\end{array}$ & $\begin{array}{l}\mathrm{P} \\
\text { Values }\end{array}$ \\
\hline X2.P1 <- Variable X2 & 0,771 & 0,770 & 0,046 & 16,814 & 0,000 \\
\hline X2.P2 <- Variable X2 & 0,794 & 0,792 & 0,047 & 17,001 & 0,000 \\
\hline X2.P3 <- Variable X2 & 0,740 & 0,735 & 0,062 & 11,857 & 0,000 \\
\hline X2.P4 <- Variable X2 & 0,850 & 0,850 & 0,028 & 29,922 & 0,000 \\
\hline X2.P5 <- Variable X2 & 0,777 & 0,778 & 0,043 & 18,202 & 0,000 \\
\hline X2.P6 <- Variable X2 & 0,825 & 0,823 & 0,056 & 14,719 & 0,000 \\
\hline
\end{tabular}

In table 2 above is known that the correlation or relationship values between indicators and variables was strong where it indicated by original sample value of each indicator which was greater than 0.5. Therefore, the relationship between indicators that made up the Government Internal Control System variable had validity value on each indicator.

Table 3. Indicator of Government Accounting Standards Variable (Variable Z)

\begin{tabular}{|l|l|l|l|l|l|}
\hline & $\begin{array}{l}\text { Original } \\
\text { Sample } \\
(\mathbf{O})\end{array}$ & $\begin{array}{l}\text { Sample } \\
\text { Mean } \\
(\mathbf{M})\end{array}$ & $\begin{array}{l}\text { Standard } \\
\text { Deviation } \\
(\text { STDEV })\end{array}$ & $\begin{array}{l}\text { T Statistics } \\
(\mid \mathbf{O} / \text { STDEV })\end{array}$ & $\begin{array}{l}\mathbf{P} \\
\text { Values }\end{array}$ \\
\hline Z.P1 <- Moderating & 0,841 & 0,839 & 0,045 & 18,699 & 0,000 \\
\hline Z.P2 <- Moderating & 0,803 & 0,802 & 0,046 & 17,530 & 0,000 \\
\hline Z.P3 <- Moderating & 0,812 & 0,809 & 0,068 & 11,863 & 0,000 \\
\hline
\end{tabular}


Competence Of Human Resources and The Government Internal Control System (SPIP) and The Effects on The Financial Statement Quality Of Public Service Agency (BLU) Moderated by Government Accounting Standard (SAP)

\begin{tabular}{|l|l|l|l|l|l|}
\hline Z.P4 <- Moderating & 0,858 & 0,851 & 0,041 & 21,091 & 0,000 \\
\hline Z.P5 <- Moderating & 0,876 & 0,871 & 0,038 & 22,946 & 0,000 \\
\hline Z.P6 <- Moderating & 0,826 & 0,825 & 0,044 & 18,972 & 0,000 \\
\hline
\end{tabular}

In table 3 above known that the correlation or relationship value between indicators and variables was strong where the value of original sample on each indicator was greater than 0.5. Hence, the relationship between indicators that made up the Government Accounting Standards variable had validity value on each indicator.

Table 4. Indicator of Financial Statement Quality of Public Service Agency (Variable Y)

\begin{tabular}{|l|l|l|l|l|l|}
\hline & $\begin{array}{l}\text { Original } \\
\text { Sample } \\
(\mathbf{O})\end{array}$ & $\begin{array}{l}\text { Sample } \\
\text { Mean } \\
(\mathbf{M})\end{array}$ & $\begin{array}{l}\text { Standard } \\
\text { Deviation } \\
(\text { STDEV) }\end{array}$ & $\begin{array}{l}\text { T Statistics } \\
(\mid \mathbf{O} / \text { STDEV|) }\end{array}$ & $\begin{array}{l}\text { P } \\
\text { Values }\end{array}$ \\
\hline Y.P1 <- Variable Z & 0,656 & 0,659 & 0,079 & 8,293 & 0,000 \\
\hline Y.P2 <- Variable Z & 0,847 & 0,849 & 0,039 & 21,780 & 0,000 \\
\hline Y.P3 <- Variable Z & 0,883 & 0,883 & 0,022 & 40,043 & 0,000 \\
\hline Y.P4 <- Variable Z & 0,884 & 0,882 & 0,025 & 34,889 & 0,000 \\
\hline Y.P5 <- Variable Z & 0,719 & 0,719 & 0,068 & 10,631 & 0,000 \\
\hline Y.P6 <- Variable Z & 0,708 & 0,716 & 0,055 & 12,897 & 0,000 \\
\hline Y.P7 <- Variable Z & 0,669 & 0,669 & 0,077 & 8,658 & 0,000 \\
\hline
\end{tabular}

In table 4 above, it is known that the correlation or relationship values between indicators and variables was strong where the value of original sample on each indicator was greater than 0.5. Therefore, the relationship of indicators that made up the Financial Statements Quality of Public Service Agency (BLU) had a validity value on each indicator.

Table 5. Path Coefficients, Mean, STDEV, T-Values, P-Values

\begin{tabular}{|c|c|c|c|c|c|}
\hline & $\begin{array}{l}\text { Original } \\
\text { Sample } \\
(\mathrm{O})\end{array}$ & $\begin{array}{l}\text { Sampl } \\
\text { e } \\
\text { Mean } \\
(\mathrm{M})\end{array}$ & $\begin{array}{l}\text { Standard } \\
\text { Deviation } \\
\text { (STDEV) }\end{array}$ & $\begin{array}{l}\text { T } \\
\text { Statistics } \\
(\mid \mathrm{O} / \mathrm{STDE} \\
\mathrm{V} \mid)\end{array}$ & $\begin{array}{l}\mathrm{P} \\
\text { Values }\end{array}$ \\
\hline Moderating -> Variable $\mathrm{Z}$ & 0,001 & $-0,006$ & 0,130 & 0,009 & 0,993 \\
\hline Moderating Effect 1 -> Variable Z & $-0,246$ & $-0,249$ & 0,121 & 2,038 & 0,042 \\
\hline Moderating Effect 2 -> Variable Z & 0,102 & 0,104 & 0,094 & 1,079 & 0,281 \\
\hline Variable of X1 -> Variable Z & 0,415 & 0,472 & 0,113 & 3,657 & 0,000 \\
\hline Variable of X2 -> Variable Z & 0,340 & 0,317 & 0,129 & 2,638 & 0,009 \\
\hline
\end{tabular}

Verification of Hypothesis H1: It was supposed that HR Competencies had significant effect on the Quality of Financial Statements of Public Service Agency (BLU).

Based on table 5 above, it showed that the relationship between HR Competency (Variable X1) and the Quality of Financial Statements of Public Service Agency (BLU) (Y) was significant with T-statistics of 
3,657 (> 1.96). The value of Original Sample was positive namely 0.415 which indicated that the direction of the relationship between the Government Internal Control System (SPIP) and Financial Statements Quality of Public Service Agency was positive. Thus, H2 in this study which stated that "the Government Internal Control System (SPIP) had significant effect on the Financial Statements Quality of Public Service Agency" was acceptable ". This is consistent with the research results of Kadek Desiana Wati et al (2014) who found that the competence of human resources had a significant impact on the quality of financial statement.

Verification of Hypothesis H2: It was supposed that the Government Internal Control System (SPIP) had significant effect on the Financial Statement Quality of Public Service Agency (BLU).

Based on the table 5 above, it showed that the relationship between SPIP and Financial Statements Quality of BLU was significant with T-statistics of 2,638 (<1.96). The value of Original Sample was positive namely 0.340 which showed that the direction of the relationship between Work Experience and Employee Performance was positive. Thus, $\mathrm{H} 1$ in this study which stated that "SPIP had significant effect on the Quality of Financial Statements of BLU" was acceptable ". This is consistent with the research result of Ni Made Sudiarianti et al (2015) which proved empirically that the application of SPIP and SAP had a positive effect on the quality of government financial statement.

Verification of Hypothesis H3: It was supposed the moderation of Government Accounting Standards was able to strengthen HR Competency on the Financial Statements Quality of BLU.

According to the table 5 above, it showed in column of T-Statistics was $2038(<1.96)$, so it could be concluded that the Government Accounting Standards as moderating variable of HR Competency had significant effect on Employee Performance. The value of Original sample showed a negative value of 0246, which meant that the variable of the Government Accounting Standards weakened the effect of HR Competency on the Quality of Financial Statements of BLU. Based on that case, it could be concluded that the hypothesis was rejected.

Verification of Hypothesis H3: It was supposed that the moderation of Government Accounting Standards is able to strengthen SPIP on the Financial Statements Quality of BLU.

According to the table 5 above, it showed in column T-Statistics was 1079 (> 1.96), so it can be concluded that the Government Accounting Standards as moderating variable of SPIP did not have significant effect on the Quality of Financial Statements of BLU. The value of Original sample showed a positive value of 0102 which meant that the variable of the Government Accounting Standards strengthen the effect of SPIP on the Quality of Financial Statements of BLU. Based on that case, it could be concluded that the hypothesis $\mathrm{H} 3$ was rejected.

\section{CONCLUSIONS}

Conclusion of this research is the HR competency significantly influences the quality of financial statements of BLU, it shows that the higher the competence level of the human resources owned by BLU then it will be better the quality of the financial statements of the BLU. SPIP has significant effect on the 
Competence Of Human Resources and The Government Internal Control System (SPIP) and The Effects on The Financial Statement Quality Of Public Service Agency (BLU) Moderated by Government Accounting Standard (SAP)

lnggrid Panjaitan

quality of financial statements of BLU. It indicates that SPIP in the environment of BLU affects the quality of BLU financial statements in which, when SPIP at BLU is better, so the quality of financial statement of BLU is better. The Government Accounting Standards (SAP) as moderating variable weakens HR competencies on the quality of the Government's financial statements but although it weakens, the result shows it is significant. The Government Accounting Standards (SAP) as moderating variable is able to strengthen SPIP on the quality of financial statements of BLU but the results is not significant.

Suggestion for further research is expected to add variables that can moderate HR competencies on the quality of financial statement of BLU and SPIP on the quality of financial statement of BLU.

\section{REFERENCES}

Edy. 2005. Penyusunan dan Analisis Laporan Keuangan Pemerintah Daerah. Yogyakarta: Andi.

http://www.ppkblu.depkeu.go.id.

http//www.bpk.go.id.

Indriasari, D., \& Nahartyo, E. (2008). Pengaruh kapasitas sumberdaya manusia, pemanfaatan teknologi informasi, dan pengendalian intern akuntansi terhadap nilai informasi pelaporan keuangan Pemerintah Daerah:: Studi pada Pemerintah Kota Palembang dan Kabupaten Ogan Ilir. Universitas Gadjah Mada.

Jannaini, Y. (2012). Pengaruh Penerapan Standar Akuntansi Pemerintah Terhadap Kualitas laporan Keuangan dan Implikasinya Terhadap Akuntabilitas Kinerja (Survei pada Dinas Kota Bandung). Skripsi, Universitas Komputer Indonesia.

Kusumah, Arif Ardi. 2012. Pengaruh Penerapan Sistem Akuntansi Pemerintahan terhadap Kualitas laporan Keuangan (Survei pada SKPD/OPD Pemerintahan Kota Tasikmalaya). Jurnal Accounting. Vol 1, No. 1.

Mardiasmo. 2002. Akuntansi Sektor Publik. Yogyakarta: Andi. Prasetya, Gede

Nur, Fadli M, Noor, Fauziah, dan Harahap, Rahmad Karim. 2014. Kapitalisasi Kontrak Ikatan Dinas Sebagai Aset Tak Berwujud Guna Meningkatkan Kualitas Laporan Keuangan Pemerintah. (Karya Tulis)

Peraturan Pemerintah No. 71 Tahun 2010 tentang Standar Akuntansi Pemerintahan

Peraturan Pemerintah No. 23 Tahun 2005 tentang Pengelolaan Keuangan Badan Layanan Umum

Ropiyantie, Devi. 2012. Pengaruh Kompetensi Sumber Daya Manusia dan Penerapan Sistem Akuntansi Keungan

Daerah terhadap Kualitas laporan Keuangan Daerah (Survei pada Organisasi Perangkat Daerah (OPD) Kabupaten Tasikmalaya). Jurnal Accounting. Vol 1, No. 1.

Sekaran, U. (2006). Research methods for business: A skill building approach. John Wiley \& Sons.

Sihombing, Binsar. 2011. Pengaruh Penerapan Standar Akuntansi Pemerintah dan Sistem Akuntansi Keuangan

Daerah terhadap Kualiatas Laporan Keungan Daerah. Skripsi. Fakultas Ekonomi dan Bisnis Universitas Pendidikan Indonesia.

Sudiarianti, N. M., Ulupui, I. G. K. A., \& Budiasih, I. G. A. (2015). Pengaruh Kompetensi Sumber Daya Manusia pada Penerapan Sistem Pengendalian Intern Pemerintah dan Standar Akuntansi Pemerintah serta Implikasinya pada Kualitas Laporan Keuangan Pemerintah.

Sukmaningrum, T., \& Harto, P. (2012). Analisis Faktor-Faktor Yang Mempengaruhi Kualitas Informasi Laporan Keuangan Pemerintah Daerah (Studi Empiris pada Pemerintah Kabupaten dan Kota Semarang). Fakultas Ekonomika dan Bisnis. 
Udiyanti, N. L. N. A., Atmadja, A. T., \& Darmawan, N. A. S. (2014). PENGARUH PENERAPAN STANDAR AKUNTANSI PEMERINTAHAN, SISTEM PENGENDALIAN INTERNAL, DAN KOMPETENSI STAF AKUNTANSI TERHADAP KUALITAS LAPORAN KEUANGAN PEMERINTAH DAERAH (Studi Kasus Pada SKPD Kabupaten Buleleng). JIMAT (Jurnal Ilmiah Mahasiswa Akuntansi S1), 2(1).

Wati, K. D., Herawati, N. T., AK, S. E., \& SINARWATI, N. I. K. (2014). PENGARUH KOMPETENSI SDM, PENERAPAN SAP, DAN SISTEM AKUNTANSI KEUANGAN DAERAH TERHADAP KUALITAS LAPORAN KEUANGAN DAERAH. JIMAT (Jurnal Ilmiah Mahasiswa Akuntansi S1), 2(1).

Wirawan, Nata. 2002. Cara Mudah Memahami Statistik 2 (Statistik Inferensia) Untuk Ekonomi dan Bisnis. Edisi ke2. Denpasar: Keraras Emas. 